\title{
THE DIALEKT CORPUS AND ITS POSSIBILITIES
}

\author{
HANA GOLÁŇOVÁ ${ }^{1}$ - MARTINA WACLAWIČOVÁ ${ }^{2}$ \\ 1,2 Institute of the Czech National Corpus, Faculty of Arts, Charles University \\ in Prague, Czech Republic
}

GOLÁŇOVÁ, Hana - WACLAWIČOVÁ, Martina: The DIALEKT corpus and its possibilities. Journal of Linguistics, 2019, Vol. 70, No 2, pp. $336-344$.

\begin{abstract}
DIALEKT, a corpus of Czech dialects, has been continuously curated and expanded by the Spoken Corpora section of the Institute of the Czech National Corpus. The following paper aims first to give a concise characteristic of the corpus, addressing its sociolinguistic parameters and possible subcorpora derivable thereof, its two-layer approach to the transcription of dialect recordings, and lemmatization $\&$ morphological tagging of the corpus. Subsequently, we move on to examples of how linguists can use the corpus and discuss two related projects which expand upon currently available possibilities: an archive of dialect-specific differential phones of the Czech language (completed) and an interactive web environment for spatial map-based visualization of data from all kinds of spoken corpora (in preparation). Thanks in part also to these additional tools, the DIALEKT corpus should serve both experts in the field as well as the general public.
\end{abstract}

Keywords: spoken corpus, dialect corpus, dialectology, corpus design, transcription

\section{INTRODUCTION}

In 2017, the Institute of the Czech National Corpus published a new specialized corpus of spoken Czech, prepared by its Spoken Corpora section: DIALEKT, a corpus of Czech dialects [1] [2]. The corpus captures and presents the traditional regional dialects present on the territory of the Czech Republic. In its first public version, the size of the corpus is approx. 100,000 words, but more data has been collected continuously and expanded versions will be published in the future. However, previous versions will also remain available in their original form so as to enable reproducible research. The corpus is accessible via the KonText web interface developed by the ICNC.

In terms of audience, the DIALEKT corpus aims to reach both language experts (dialectologists, other linguists, and researchers from related fields) as well as amateurs from the general public. It is also expected to serve as a teaching resource at all education levels [3].

The goal of this paper is to introduce the first public version of the DIALEKT corpus and to showcase its possible uses, including resources and tools derived from the corpus which either already exist or are being currently worked on. 


\section{COMPOSITION AND AIMS OF THE DIALEKT CORPUS}

\subsection{Composititon of the DIALEKT corpus}

The DIALEKT corpus consists of speech recordings made in all traditional dialect regions of the Czech Republic and their transcripts. The current version contains 324 recordings of a total length of 13 hours, comprising 178 unique speakers. The number of speakers is influenced by the fact that dialectological recordings are relatively short (approx. 1-6 minutes, typically 2 minutes), because they mostly focus on one person's account of a single topic. In terms of territorial coverage, the corpus features recordings from all dialect regions of the Czech Republic, including Czech language islands in Poland. For the time being, it does not include recordings from the Bohemian, Moravian and Silesian borderlands, which, however, do not belong among traditional dialect regions. Because of massive population relocation after World War II, these formerly mostly German-speaking areas lack a traditional dialect substrate. As far as word counts are concerned, the individual regional categories are currently not represented evenly. Plans for the immediate future do not include attempts at balancing this out, our main goal is to collect and publish as much data as possible.

\subsection{Data collection}

The recordings collected in the corpus come from a variety of sources, thanks to which they cover a fairly long time span. They are divided into two time strata, older and newer, and this information can be used to constrain searches or other operations involving the corpus. The older stratum consists of recordings made from the late 1950s up to the 1980s. Part of this material was collected by the Department of Dialectology of the Czech Language Institute of the Czech Academy of Sciences and published in the Addenda to the Czech Linguistic Atlas [4]; the rest comes from private collections, which for the most part have also been previously published. The new stratum then spans recordings from the 1990s up to the present day. This new stratum encompasses recordings made in the course of research activities at various universities, by private individuals, and last but not least, also by the Institute of the Czech National Corpus itself.

The data collection methodology follows the principles usually applied in the field of Czech dialectology. The recordings are mostly informal in nature, even though many of them were obtained within the structured interview research paradigm, i.e. with researchers interviewing subjects. The result is unprepared discourse, predominantly monologues, captured in the private setting of the subject's home. Topics focus on the traditional rural way of life, covering agriculture, arts $\&$ crafts, local customs and traditions, contemporary events etc. More specifically, we encounter e.g. recipes for regional dishes, descriptions of crafts like weaving, accounts of Christmas and Easter, memories of the beginning of World War II, or local legends. 
For the moment being, our goal is to capture the most archaic state of the traditional regional dialects and we are not concerned with generational differences. Correspondingly, the recordings only feature members of the oldest generation still alive, so as to capture as many of the original dialect features as possible. Informants were selected from among local natives in rural areas who belonged to the settled stratum of the population, mostly spent their entire lives in that one place, and were tied to an agricultural way of life or a particular craft. They all fall into the $60+$ age group, in other words, they were born between the late $19^{\text {th }}$ century and the middle of the $20^{\text {th }}$ century.

\subsection{Sociolinguistic characteristics and creation of subcorpora}

The DIALEKT corpus contains detailed sociolinguistic characteristics of the speakers and the communication situation captured in the recording, thanks to which the dialectological material can be sorted into various groups. One of the userfriendly ways of achieving this is by defining subcorpora in KonText. Recordingrelated metadata comprise detailed information about the place of recording, e.g. type of locale (urban, rural) and its size, geographical localization - country, region (Bohemia, Moravia, Silesia), dialect group (skupina), subgroup (podskupina), division (úsek) and type (typ). Additional characteristics of the communication situation include source of the recording (e.g. an institution), recording date, time stratum membership (older vs. newer), main topic, type of discourse (monologue, dialogue, and combinations thereof), number of speakers, and presence of a researcher. Speaker-wise, we also track a range of metadata, from gender, age, education, place of residence in childhood and longest place of residence (including detailed dialectological classification), to the speaker's longest professional occupation. All of this information can be displayed in the KonText corpus interface and used to retrieve frequency statistics. Most of these sociolinguistic characteristics can also be used to define subcorpora. For instance, if we are interested in phonelevel phenomena in north-east Bohemia, we can either restrict our search on-the-fly using KonText's Restrict search functionality, or we can create our own permanent subcorpus based on this dialect region, which will always be available after logging in and can be used for repeated searches.

\section{PROCESSING DATA}

\subsection{DIALEKT's two-layer approach to the transcription of dialect recordings}

Dialect recordings intended for the DIALEKT corpus are transcribed using the ELAN annotation software (much like those for ORTOFON [5], a corpus of informal spoken Czech conversations). There are two parallel transcription layers, a dialectological one and an orthographic one (i.e. a base transcript). These are timealigned to the sound recording, along with auxiliary layers capturing additional 
paralinguistic information concerning the individual speakers' utterances or the entire communication situation. In the KonText corpus interface, it is possible to search either the dialectological or the orthographic layer separately, or both at the same time, similarly to a parallel corpus with the same documents in multiple languages. Results can also be displayed in this parallel corpus mode, with both layers standing side by side.

The transcription on the dialectological layer follows the approach traditionally used in Czech dialectology, as outlined in the Rules for the Scientific Transcription of Dialectological Records of Czech and Slovak [6] and applied e.g. in the compendium of Czech Dialect Texts [7] or in the Addenda to the Czech Linguistic Atlas [4]. The goal of the transcription is to faithfully capture what the speaker said, in the context of the framework of systematic description of Czech dialects. Differential dialect phones are encoded with special purpose symbols, as traditionally used in dialectological transcripts (e.g. $\ddot{a}$ stands for a fronted $a, e$ for an open $e, t$ for a dark $l, w$ for a bilabial $v$ etc.). Sentence punctuation follows the standard rules of written Czech, but sentences do not start with a capital letter.

jennou vo Wánocich tatỉnek poudal, že... mňel ňáki známi v Helkovicich, tag že se tam pújdem pod'wat', mñe üzal taki na ližich.

'once at Christmas Daddy said, that... he had some friends in Helkovice, so we would go to see them, he took me on skis too'

The transcription on the orthographic layer is very similar to the general rules currently applied to regular spoken corpora of the Czech National Corpus [5], [8]. It is fairly close to usual orthography, but diverges from it in trying to capture some characteristic features of spoken language and some regional phenomena. In order to make lemmatization and morphological tagging possible, phone-level differences in word roots are disregarded and overridden by the standard form. Vowel length is also standardized (even in Silesian varieties with systematic shortening). However, morphological variation is kept as is, e.g. endings of all types of declension (synoj vs. standard synovi 'son' (dative)) and conjugation (nosijó vs. standard nosí (pl.) 'they wear'). Dialectal or regional lexis (calta 'Christmas cake', zemák 'potato', ostat 'to stay') is preserved, and if no parallel exists in the standard language, no artificial standardization of the root is attempted (kutky 'open fireplace'). As for punctuation, unlike the dialectological layer, the orthographic layer has pausal punctuation.

jednou vo Vánocích tatínek povídal že .. měl .. nějaký známýv Helkovicích .. tak že se tam půjdem podivat .. mě vzal taky na lyžich

'once at Christmas Daddy said, that... he had some friends in Helkovice, so we would go to see them, he took me on skis too' 
Having two different transcript layers and being able to search them both even at the same time, as parallel corpora - has many advantages. The dialectological layer allows for highly specific searches targeting various possible phone-level realizations of words (e.g. chcel, cht'll, cht'el 'he wanted'). On the other hand, if we start from the orthographic layer, we can search for a standardized word form (e.g. byli 'they were') and retrieve all of its pronunciation variants recorded on the dialectological layer (bili, buli, boli, beli, byti 'they were').

The pausal punctuation of the orthographic layer can also be used to elucidate some phenomena present on the dialectological layer. For instance, the occurrence of a pause can explain why an expected voicing assimilation across word boundaries failed to materialize. The usual case, where voicing assimilation across word boundaries does happen, is illustrated by the following example:

\section{dialectological layer: tam šlo přez brambori takovi dlouhi strašidlo velkí \\ 'such a long, big specter went across the potato field' \\ orthographic layer: tam šlo přes brambory takový dlouhý strašidlo velký}

(the absence of punctuation indicates that this stretch of speech was uttered without pauses)

In contrast to this, the missing voicing assimilation across word boundaries on the dialectological layer in the next example can be explained by the presence of a pause, which is recorded on the orthographic layer:

\section{dialectological layer: voňi zas bili rádì, že se s ňima bawíme 'they were glad again we were talking to them' (contrast with expected realization zaz bili 'again were') ortografická rovina: voni zas . byli rádi. že se s nima bavíme (the period indicates a very short pause)}

\subsection{Lemmatization and morphological tagging of the corpus}

The DIALEKT corpus offers fairly rich linguistic annotation of the transcripts - it is lemmatized and morphologically tagged. Lemmas are always taken from standard language and subsume all non-standard forms of a word. In other words, they encompass not only all inflected forms of a word, but also all regional pronunciations of those inflected forms (e.g. even chcu 'I want', cht'et 'he wanted', sceli 'they wanted', etc. will all be lemmatized as chtit 'to want'). A lemma-based search therefore makes it possible to recover all inflected forms of a given word in all their regional variants. The lemmatization is the same for both transcription layers and yields corresponding results when searching on either one.

Each token is also assigned a morphological tag consisting of 16 characters (mostly letters) encoding various morphological categories (e.g. aňi ti slova NNNP4- 
----A---- neumím použivat 'I can't even use those words'). When searching by morphological tags, the result set consists of all matching word forms in all their recorded pronunciation variants.

The process of lemmatization and tagging was made difficult by the high variability of the dialect material and a lack of specialized training data. In spite of this, the resulting annotation is relatively accurate and yields fairly reliable search results. Users of the corpus can thus rely on lemma and tag searches to their advantage, making it easier to explore the Czech language system in all its regional diversity.

\section{POSSIBLE USES, RESOURCES AND TOOLS}

\subsection{Example use cases of the corpus}

Dialect variants from all levels of linguistic description (phonetics \& phonology, morphology, syntax and lexis) can be found in the DIALEKT corpus. Even though it ranks among smaller corpora in terms of size, it faithfully captures a range of phonelevel dialect specificities. The corpus allows us to track their conditions of use - not only with respect to their territorial spread, but also in relation to speaker or context characteristics. This makes it possible to track the lexicalization of phone-level phenomena. It turns out this type of lexicalization does not only affect frequent words, but also specific groups of words. It mostly occurs with words related to a given region, its climate, typical way of life and arts \& crafts; also affected are proper nouns, in particular toponyms and anthroponyms, and occasionally also expressive words (the recordings offer a somewhat limited range of expressivity, being monological in nature). Considering for instance the rounded pronunciation $w$, a relict of the original bilabial pronunciation, we can confirm it occurs in the northeast Bohemian dialect region, predominantly with male speakers. It is particularly well-documented in frequent words like pronouns (won 'he', takowej 'such'), but also with regional expressions (tkalcowat 'to weave'), toponyms (chodil na vistavi do Trutnowa 'he went to Trutnov for exhibitions'), and anthroponyms (menoval se Schowánek 'his name was Schovánek'). In the north-east Bohemian dialect region, we can also find cases where the $t$ phone and the $y$ variant are lexicalized. Dark $t$ is encountered predominantly in the past participle of verbs (byt 'he was', vzat 'he took', šet 'he went', vodettret 'he opened', dat 'he gave'), $y$ is used in forms of the word být 'to be', and systematically in conjunction with dark $t$ (before or after it), which indicates lexicalization (była perletej vikládaná 'it was inlaid with nacre').

Among other things, the companion website to the DIALEKT corpus lists many tips for working with the corpus, which can be useful e.g. for lexicographical work. A succinct overview is given of the basic techniques for working with the corpus, including search, display of various types of information, and sorting of search results. The process of creating both simple and more complex search queries, 
convenient especially for lexicographers, is then documented using examples (searching e.g. for all words beginning with the letter $b$, for a specific word form, for a substring, for multi-word sequences, etc.). When searching for words beginning with a given letter, the lexicographer can also generate a frequency list of matching lemmas or word forms which can be used to determine whether a target lexical unit is present in the corpus or not, and if present, then in what precise form. In addition to these lexicographical tips, detailed instructions are provided on how to create subcorpora, which can also be very helpful in working with the corpus data.

\subsection{Archive of dialect-specific differential phones of the Czech language}

The companion website of the DIALEKT corpus also features an overview of the dialect phones [9] occurring on the territory of the Czech Republic and the corresponding symbols used in dialectological transcripts. For each dialect phone, an accessible description is given, complemented with information about territorial spread within the Czech Republic and examples of use in context in the form of a short recording excerpt and its transcript (bêlê mladí 'they were young', košyg je hotovy 'basket is finished', že být 'that he was', p'ekne 'pretty', ośm 'elit 'he mustered the courage'). The year of each recording is also indicated. These examples of differential phones specific to various Czech dialects were selected from the material of the corpus, i.e. from authentic dialect data. We strive to represent dialect vowels and consonants by the most typical examples available, avoiding transitional or otherwise unusual realizations. This archive of dialect-specific differential phones of the Czech language is not only a very useful tool for our own internal needs, but it can also serve other dialectologists, both professional and amateur, working on transcribing dialectological material. Last but not least, it constitutes an interesting teaching resource at all education levels.

\subsection{Interactive map-based web environment}

We are gradually putting together an interactive web environment which integrates language data from $\mathrm{CNC}$ corpora with a map-based interface. We are currently revising the classification of individual municipalities with respect to the system of dialect areas [11], which is a fairly demanding work, done in collaboration with cartographer K. Kupka and dialectologists from the Czech Language Institute of the Czech Academy of Sciences. One of the results of this effort should be an interactive map visually anchoring the recording locales of the DIALEKT corpus within the system of dialect areas. At selected representative dialect points of interest, it will be possible to display additional information about the characteristic features of the corresponding dialect region, division (úsek) and type (typ), as well as a short transcription sample together with an analysis and/or a recording of dialect speech. Users will also be able to cross-reference speakers and recordings from the same or neighboring locations across the DIALEKT corpus and other spoken corpora 
of the $\mathrm{CNC}$, making it easier to contrast and compare different sources of information about the territorial spread of a given phenomenon [12]. The interactive web app format offers advantages over the traditional visualization of language phenomena on static maps (e.g. in language atlases [13], [14]). It can be attractive not only for professional and classroom use, but also for the general public, both for educational and entertainment purposes, e.g. in the form of a quiz.

\section{CONCLUSION}

At the SLOVKO 2015 conference, plans for the DIALEKT corpus and related future outlooks were presented [10], which can now be confronted with what has actually been achieved so far. The intended final size of the corpus was cca 200,000 words. The first stage of the corpus, which is currently publicly available, totals 100,000 words. We expect that the second stage, which will be completed and published in 2020, will add another 100,000 words, thus reaching the initial goal. As initially planned, two transcription layers are available for searching - dialectological and orthographic transcripts. They are aligned to sound recordings, which are divided into short segments. For the moment being, it is not possible to play back entire recordings at once, but this remains a planned feature for one of the future versions of the corpus. It is encouraging that even in its first version, the DIALEKT corpus has already become a valuable resource both for linguistic research and teaching. For instance, it is one of the resources used in the process of compiling the territorially comprehensive Dictionary of Czech dialects. The data in the corpus were also used to create the Archive of dialect phones of the Czech language, and an interactive web environment which is currently in preparation and planned to be launched by the end of 2019.

\section{ACKNOWLEDGMENTS}

This paper resulted from the implementation of the Czech National Corpus project (LM2015044) funded by the Ministry of Education, Youth and Sports of the Czech Republic within the framework of Large Research, Development and Innovation Infrastructures.

\section{References}

[1] Goláňová, H., Waclawičová, M., Komrsková, Z., Lukeš, D., Kopřivová, M., and Poukarová, P. (2017). DIALEKT: nářeční korpus, verze 1 z 2. 6. 2017. Praha, Ústav Českého národního korpusu FF UK. Accessible at: http: / / www . korpus . cz

[2] Goláňová, H. - Waclawičová, M. (2018). Co je v ČNK nového IX (Zprávy z českého národního korpusu). Korpus - gramatika - axiologie, 2018 (17), pages 78-82. 
[3] Waclawičová, M., and Goláňová, H. (2019). Nářeční korpus DIALEKT a jeho použití ve výuce češtiny. Český jazyk a literatura, 69(3), pages 127-133.

[4] Balhar, J. et al. (2011). Český jazykový atlas Dodatky. Praha, Academia.

[5] Kopřivová, M., Komrsková, Z., Lukeš, D., Poukarová, P., and Škarpová, M. (2017). ORTOFON: Korpus neformální mluvené češtiny s víceúrovňovým přepisem. Praha, Ústav Českého národního korpusu FF UK. Accessible at: http: / / www . korpus. cz

[6] Dialektologická komise České akademie věd a umění (1951). Pravidla pro vědecký přepis dialektických zápisů českých a slovenských. Praha, Česká akademie věd a umění.

[7] Lamprecht, A., and Michálková, V. et al. (1976). České nářeční texty. Praha, Státní pedagogické nakladatelství.

[8] Kopřivová, M., Lukeš, D., Komrsková, Z., Poukarová, P., Waclawičová, M., Benešová, L. and Křen, M. (2017). ORAL: korpus neformální mluvené češtiny, version 1 as of 2 June 2017. Praha, Ústav Českého národního korpusu FF UK. Accessible at: http://www . korpus.cz

[9] Goláňová, H., and Waclawičová, M. (2019). Archiv diferenčních hlásek nářečí českého jazyka. Version as of 26 February 2019. Praha, Ústav Českého národního korpusu FF UK. Accessible at: http: / / www . korpus.cz .

[10] Goláňová, H. (2015). A new dialect corpus: DIALEKT. In Gajdošová, K., and Žáková, A. (eds.). Proceedings of the Eight International Conference Slovko 2015 (Natural Language Processing, Corpus Linguistics, Lexicography). Lüdenscheid, RAM-Verlag, pages 36-44.

[11] Goláňová, H., and Kupka, K. (2019). Mapa nářečí českého jazyka. Version as of 9 January 2019. Praha, Ústav Českého národního korpusu FF UK. Accessible at: http://www . korpus.cz

[12] Goláňová, H., Kopřivová, M., Lukeš, D., and Štěpán, M. (2015). Kartografické a geografické zpracování dat z mluvených korpusů. Korpus - gramatika - axiologie, 2015 (11), pages 42 54.

[13] Balhar, J. et al. (1999, 2002, 2005). Český jazykový atlas 3, 4, 5. Praha, Academia.

[14] Balhar, J., and Jančák, P. et al. (1992, 1997). Český jazykový atlas 1, 2. Praha, Academia. 